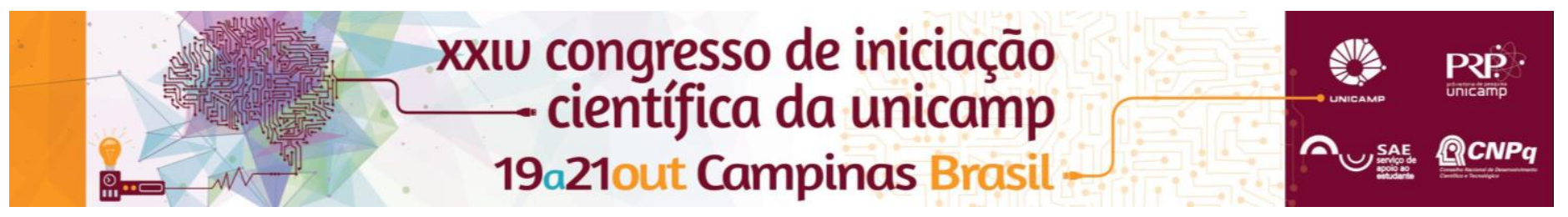

\title{
The Piauí Herald e Desnotícias: um estudo discursivo do humor.
}

\section{Filipo Pires Figueira*}

\begin{abstract}
Resumo
Para esta pesquisa, assume-se que o humor é um campo discursivo, Um campo tem regras de funcionamento específicas, bem como gêneros discursivos que fizeram e fazem história no campo. O objetivo foi analisar um gênero discursivo emergente neste campo discursivo, a "desnotícia", de presença originalmente online. Fizeram parte do corpus desnotícias do blog the Piauí Herald, integrante do site da revista Piauí. As análises foram feitas a partir da Análise do Discurso francesa, contanto também com teorias do humor, bem como com alguns conceitos da psicanálise. O foco das análises foi o funcionamento da memória discursiva e da cenografia, a partir da alusão a acontecimentos.
\end{abstract}

\section{Palavras-chave:}

Análise do Discurso, Humor, Desnotícia.

\section{Introdução}

Desnotícia é um gênero discursivo emergente, de origem virtual, publicado em páginas online, como blogs ou sites. Apresentam muitas características em comum com a notícia, mas se diferenciam dela em um ponto crucial: enquanto a notícia trata do fato - e, de alguma forma, da verdade -, a desnotícia explora o campo do humor e do riso; i.e., utiliza o acontecimento como meio, não como fim, para criar enunciados cômicos. Assim, elas "emprestam" da notícia algumas características, como a remissão a acontecimentos e a pessoas públicas ou a construção formal do texto, entre outras. No entanto, é claramente explicitada (ao leitor atento) sua diferença em relação à notícia: seja porque os sites confessam que as "notícias" são falsas, seja pelo teor zombeteiro e fictício dos relatos apresentados.

Visto que são, portanto, paródias - textos que buscam subverter o sentido daquele primeiro que the deu origem $^{1}$-, o objetivo desta pesquisa é compreender como a desnotícia utiliza-se dos elementos da notícia e, principalmente, da memória de seus leitores (dos eventos e do próprio jornalismo) para conseguir narrar uma mentira e, ainda assim, fazer rir.

As análises basearam-se na escola francesa da Análise do Discurso, e tiveram como pressuposto teórico as noções de primado do interdiscurso ${ }^{2}$ e de campo discursivo ${ }^{3}$ : isto é, que os discursos, ao formularem-se, formulam sempre seu Outro, seu interdito, mas, também, que estes organizam-se em campos, com procedimentos e formulações relativamente homogêneas. Consideramos, também, teorias do humor, que defendem que o riso é fruto de uma quebra de expectativa ${ }^{4}$.

\section{Resultados e Discussão}

Selecionamos, assim, 11 textos exemplares a serem analisados, retirados todos do blog The Piaul Herald, blog da revista Piauí. Foram 3 os aspectos analisados: (a) a presença e função da memória discursiva nas produções textuais; (b) o uso cenográfico da estrutura formal da notícia pelas desnotícias; e (c) aqueles enunciados que, mesmo mantendo as mesmas relações dos itens anteriores, baseavam sua graça no equívoco fundamental do discurso e da língua, i.e., na sua possibilidade de falhar, de desviar o sentido.

Primeiramente verificamos que as desnotícias baseiam suas narrativas em eventos e personagens públicos reais, bem como nos discursos socialmente produzidos sobre eles. Desse modo, torna-se fundamental que o leitor, ao ler as desnotícias, retome as alusões e remissões operadas nos textos - que passe por esse teste de inteligência de reconhecimento.

Outro tipo de memória foi também analisada: desta vez, a memória discursiva sobre a notícia e sobre o jornalismo. Observamos que a desnotícia, em sua cena de enunciação ${ }^{5}$, apresenta-se cenograficamente como notícia, afim de parodiá-la e complexificar o teste de inteligência para seu leitor.

Por fim, analisamos também os enunciados humorísticos que são fruto do equívoco, da impossibilidade de univocidade de sentido. Percebemos que há, de fato, enunciados elaborados através do duplo sentido e da ambiguidade, mas que nunca apresentam-se desvinculados de uma narrativa que alude à acontecimentos reais.

\section{Conclusões}

Concluímos a pesquisa com a hipótese de que as desnotícias analisadas apresentam-se como uma tripla armadilha aos seus leitores: primeiro, como uma charada, em que estes precisam decifrar e retomar os elementos remetidos de forma a interpretá-las; segundo, como encenação, que complexifica a charada e finge enunciar uma mentira como verdade; e, por último, como equívoco, por basear-se nos desvios de sentido da língua, mas também por explorar a falha constitutiva do discurso

Isto posto, a desnotícia é o interdito da notícia: a narrativa que ela não pode narrar. E a notícia, por sua vez, é discurso sério que se faz pano de fundo para que as desnotícias possam emergir.

\section{Agradecimentos}

Agradeço à FAPESP pelo apoio e pelo fornecimento da Bolsa de Iniciação Científica.

\footnotetext{
1 Sant'anna, A. PARÓDIA, PARÁFRASE \& CIA. São Paulo: Ática, 2003.

${ }^{2}$ Maingueneau, D. Gênese dos discursos. Curitiba: Criar Edições, 2005.

${ }^{3}$ Possenti, S. Língua, Humor e Discurso. São Paulo: Editora Contexto, 2010.

${ }^{4}$ Bergson, H. O Riso. São Paulo: Martins Fontes, 2001.

${ }^{5}$ Maingueneau, D. Discurso Literário. São Paulo: Contexto, 2006.
} 